\title{
From Metics to the Erased, or How to Ground Cosmopolitanism: A Post-Socialist Perspective on Current Theories of Cosmopolitanism
}

\author{
Ksenija VIDMAR HORVAT \\ Department of Sociology, Faculty of Arts, University of Ljubljana, Slovenia \\ ksenija.vidmar@ff.uni-lj.si
}

\begin{abstract}
The paper is a critical contribution to contemporary theory of cosmopolitanism which takes into account specific socio-cultural and political contexts of postsocialist Central and Eastern Europe. It is argued that in order for cosmopolitanism to become effective politics and the practice of democratic citizenship, it has to be grounded in daily processes of negotiation of loyalty and patriotism to the national society. In this regard, it should not be conceptualised as nationalism's other but rather as an alternative patriotic sentiment, which combines the global ethos of humanity and responsibility towards political and cultural organization of local social life. The paper illuminates this approach from the perspective of post-socialist citizenship in Slovenia and the tragic experience of the "erased".
\end{abstract}

Key words: cosmopolitanism, citizenship, post-socialism, nationalism, Balkan, ex-Yugoslavia, Slovenia

\section{Introduction}

The paper investigates the relationship between cosmopolitanism, patriotism and nationalism in post-1989 Europe.* The concern is both theoretical and political. Since the collapse of the Berlin Wall, Central and Eastern Europe has witnessed the rise of xenophobic nationalism. Its vitality, despite internal democratic processes and external pressures of Europeanisation (exhorted mainly in the form of EU conditionality), is far from being exhausted. To

\footnotetext{
* The research for this paper has come from the project "The Challenges of Europeanisation: Mediating between National and European Identities in South Eastern Europe" (SEUM, 2010-2011), sponsored by ASO (Austrian Science and Research Liaison Office), Ljubljana (www.seumproject.eu).
} 
the contrary, the observation offered by Delanty in 1996, that in this part of Europe, the scenario of the return "to the history" gave the xenophobic forces of ethnic nationalism "a legitimation for their cultural politics of exclusion" (Delanty, 1996: 94), in many ways still holds true; xenophobia, in particular Romaphobia and Islamophobia, but also other expressions of extreme and far-right nationalism in the region, have become exacerbated.

The "social fear of the others" (Delanty, 2008) has also become a shared experience in the "old Europe". In Western European societies such as The Netherlands and the UK, in which multiculturalism has been the standard for managing social relations (based on ethnic and cultural understanding and tolerance), popular sentiments and political rhetoric have changed dramatically. Van Wichelen and De Leeuw provide the current picture for The Netherlands when they write that the country "has transformed from a multicultural welfare-state in the 1990 s to a country with an identity crisis whose citizens have increasingly started to support extreme right parties" (Van Wichelen and De Leeuw, 2008: 121). Recent developments in France where in 2010 - only a year after the Dosta! Campaign, put in place by the Council of Europe to enhance positive attitudes towards the Roma, and two years after the European year of Intercultural Dialogue - expulsion of the Roma was carried out under state sponsorship further attests of the collapse of the key EU values of humanism, tolerance and solidarity across the spectrum of Western democracies. Angela Merkel's announcement of the "end of multiculturalism" in Germany and David Cameron's similar statement as regards the UK are good enough reasons for public concern, too, that Europe is giving up on its core commitment to cherish cultural diversity and further intercultural dialogue.

Political denouncements of European multicultural societies certainly are not a proper reflection of reality - multicultural society is not a matter of political decision! (McGhee, 2008) - but they surely provide ample ammunition to the nationalist desire to salvage the "traditional", "autochthonous", "native" European identities and, as a consequence, counter the social and cultural impact of the postmodern, globalised world of hybridisation and mélange. If at all sensitive to these issues, social theory needs to raise the question of how to confront these developments. In particular, are there theoretical models and conceptual tools that can challenge these trends? Could cosmopolitanism be one of the formulae to provide a viable alternative and create a new politics of identity which, in addition to the privileged globe-trotting cosmocrats (Vertovec and Cohen, 2002: 6), would also be available to ordinary people? And how would this "ordinary" cosmopolitanism (Hiebert, in Vertovec and Cohen, 2002: 5) fit into 
the national frame which, despite growing evidence for the emergence of a post-national era, is still the defining moment for the politics of citizenship and belonging (Benhabib, 2006; Rizman, 2008)? In what ways could the cosmopolitan imagination challenge racism and social phobias - matters that are being borne on discourses of nationalism and which, particularly in Central and Eastern Europe, are being presented as issues of "security", "protection" and "self-defence" of the majority (Forrester, Zaborowska and Gapova, 2004; Kymlicka, 2007)?

Our analysis thus asks how cosmopolitanism can be integrated into the democratic politics of belonging of the national societies and how a cosmopolitan subject can claim a role of the adversary in the negotiation of the collective identities in the emergent post-national era. In the time of globalisation of the world (Featherstone, 2006; Delanty and Rumford, 2005; Habermas, 2001; Rumford, 2008; Turner, 2002), the focus on the national society may seem an anachronism (Kristeva, 1993), yet it is chosen on purpose. Namely, in addition to above-mentioned movements away from the open society model, whose sources lie in part within failed European policies of co-existence, globalization, too, has triggered many different processes of which the evolving cosmopolitan agenda is only one. Equally ostensible, notwithstanding its force of violence, is the rising xenophobic and racist attitude towards the immigrants, the asylum seekers, the undocumented and the refugees ... - the "other" Europeans whose presence within and on the borders of the EU Schengen fortress has been a visible reminder of the corroding of the European project of just society (Balibar, 2004). Therefore, although cosmopolitanism presumes a world view that is above the local and the national, it will be the contention of this paper that cosmopolitanism can only be operationalised as a democratic alternative to processes of exclusionary nationalisation and discriminatory practices of societies if it (re)claims its locality. Cosmopolitanism is governed by an ethos of global concern for humanity, especially the underprivileged and marginalised, and is an advocate of a just global order in which the "others" take part in the post-national social contract as equals (Appiah, 1997; Benhabib, 2004, 2006; Nussbaum, 1994). Both these missions, however, can be accomplished only when the cosmopolitan subject becomes actively engaged in local social life. The migrating strangers and the "aliens" of today's world, who so easily get compared to the cosmopolitan ideal of detachment from one's own culture, are indeed dislocated and dispossessed of their native homelands; but it is their exclusion and suffering that unfolds within the localised territories of the nation states, not an abstract world of 
global citizens, which forces their up-rootedness to become a re-localised trauma (see especially Calavita, 2005).

Therefore, for an active role that cosmopolitanism could play in processes of democratisation of citizenship and belonging, it is necessary to acknowledge its responsibility towards local life. To provide a critical outline for the "grounding" of cosmopolitanism, the paper employs recent theoretical accounts that emphasise the need to translate cosmopolitanism's philosophical roots into a social practice (Calhoun, 2008; Skrbiš, Kendall and Woodward, 2004). The contribution of this analysis, however, is that it underlines the need to bring cosmopolitan practice into a historical perspective. That is, in contrast to authors who focus on "ordinary" cosmopolitanism in light of a trans-historic experience, which re-emerges in different social contexts and historical times, this study emphasises the need to bring cosmopolitanism into historical relationship, especially in relation to its nationalist predecessor. It is argued that the notion of territoriality presents a crucial component in the cosmopolitisation of national patriotic sentiment. This is supported by the experience of the "erased" in Slovenia, whose status of territorial belonging to the nation changed, not by the fact of migration or exile or other type of movement, as is the case with migrants; nor by the change of borders, as is the historical experience of ethnic minorities. They became uprooted aliens while staying immobile in the same place, residing on the same soil, occupying the same territory. The case of the erased thus demands a fresh theoretical look at the ways to challenge state and public regimes of exclusion by the means of cosmopolitan politics of territory and territorial belonging.

The paper proceeds in three steps. First, it offers a brief overview of the cosmopolitan heritage in Europe; second, it places the cosmopolitan agenda, accumulated from the past to the present, against the most recent challenges of citizenship as they emerge in the contexts of global mobility and migration. Finally, we discuss the cosmopolitan project within the contexts of post-socialist Slovenia and in particular of the experience of citizenship within the new independent democratic state. The goal of this localisation of the debate is to bring cosmopolitanism back to the ground - social, historical, political and cultural - and to exercise a critical stand by which post-socialist perspective(s) can be incorporated into the theory of cosmopolitanism.

\section{The cosmopolitan agenda from past to present}

Looking at the legacies of cosmopolitanism and cosmopolitan practices in Europe, a defining moment can be located in the state of "up-rootedness" 
(Benhabib, 2004, 2006; Delanty, 2005, 2009; Held, 2003; Marotta, 2010; Ossewaarde, 2007; Skrbiš, Kendall and Woodward, 2004; Vertovec and Cohen, 2002). In the past, the denial of territorial bonding was usually also the denial of citizenship. In ancient Greece, metics were non-citizens. As the etymology of the word (métoikos, indicating change, and oîkos, dwelling), conveys it, metics came from elsewhere to settle temporarily in the cities as artisans, participating also in trade and education. In the period of Solon, foreigners were actually invited and offered citizenship. However, soon, the promise amounted only to carrying the burdens of citizenship without sharing in the privileges. The burden included military service and special taxes. Metics were integrated in social and economic life but had no political rights. As resident foreigners, they could participate in the Greek economy but with no succession rights (Kristeva, 1993: 19). Although they were not a homogenous group - they could be either ex-slaves living in poor conditions or wealthy city dwellers, hardly distinguishable in public from the citizens, metics attracted ambiguous aura. Homer attacked these early cosmopolitan figures as "clanless" and "heartless". To this negative attitude towards the early immigrants, Vertovec and Cohen add how Homer's own hero, Odysseus, could be listed as a cosmopolitan. Of Odysseus, who sought adventure and valued the unfamiliar and the strange, they write, "We can see in this earliest of literary examples the powerful tension between the exciting, stimulating and even arousing attractions of the exotic, and the converse desire for the support, consolation and warmth of the local and familiar" (Vertovec and Cohen, 2002: 5).

In addition to the early cosmopolitans whose ethos of mobility was fuelled by pressures of both forced and voluntary migration, the most important source for historical revisiting of past cosmopolitanism are philosophers, in particular Greek cynics and Roman stoics. The cynics' aim was to transcend the Greek polis; stoics built their philosophical agenda around the idea of a universal state - a cosmopolis. For the stoics, the polity was based on the universalism derived from the humanity of every man: megapolis embraced the ideal of reaching out to the entire universe, "from citizens to the stars, including Greeks and barbarians as well, slaves and free men" (Kristeva, 1993: 20). The moral concern and civic loyalty went to two communities, the local community of one's birth and the community of humanity. The world citizen was not necessarily entirely detached from his creed and local identification. But because the accident of the birth was just that - an accident - the prime loyalty went to humanity. As Diogenes and his successors understood it, differences of class or ethnicity or gender 
were no justification for divisions. They may have been (and in fact have been) sources of temporal power and form of government, but the world citizens' loyalty was to the "moral community made up by the humanity of all human beings" (Nussbaum, 1994: 3).

The philosophical and moral tradition of stoicism, based on the universalism of human beings, continues in the philosophers of the Enlightenment. The debate concerns the division between the right of the man and the right of the citizen. Montesquieu granted the primacy to the rights of man, which would be the protecting agency of "privacy", "shyness", "weakness"; so did Diderot, who "inserts strangeness into us" (Kristeva, 1993: 28). As Kristeva reminds us, revolutionary terror was first directed against foreigners, whereas nationalism defeated the universalism with destructionism whose consequences could be fully studied only with the rise of Nazism. Despite this, Kristeva also sees the division between universalism and nationalism, human rights and the rights of the citizen, a politically empowering as it becomes psychologically duplicated within the self. In fact, she goes so far as to see this as a formula of coping with the issue of immigration: "It thus links its own adventure with the mediations each one of us is called upon to engage in when confronted with the fascination and horror that a different being produces in us, such meditations being prerequisite to any legal and political settlement of the immigration problem" (Kristeva, 1993: 30).

In cosmopolitan writing, the dangerous allure of the alien, the strange, and the unfamiliar often prevails over the comforting image of the domestic and homely. To be a cosmopolitan requires skill, competence and courage to detach oneself from the safe-haven of the known and the familiar; it demands the exercise of enduring on oneself the aura of the stranger to the community, and to live consciously with the consequences of the estrangement. The flip side of the coin is the gratification in experiencing the uniqueness of the self: self-alienation itself becomes a terrain of mastering freedom and (of) individuality against the pressures of group identity and definition. In Kristeva, the rewarding moment is clearly explicated when she links the cosmopolitan ethos to the subjective, individual experience of estrangement by intellectuals (such as herself), women, artists, and self-appointed exiles who, again like her, travel to foreign lands to assimilate in the amorphous social body consisting of foreigners and strangers. "On American soil", she makes the destination of this liberation quite explicit, "I feel a foreigner just like all the other foreigners. And I believe that together we can build something from this solidarity because we all belong to a future type of humanity 
which will be made entirely of foreigners/strangers who try to understand each other" (Kristeva, 1998, cited in Varsamopoulou, 2009: 38). Writing on "cosmopolitan virtue", Bryan S. Turner provides a similar celebratory narrative of strangeness, coupled with self-distancing and ironic relation towards one's own culture and local community. The "capacity for ironic distance and regard for others" (2002: 55) in Turner's view is both a prerequisite for the nurturing of the cosmopolitan virtue; and the gratifying outcome, which liberates oneself from engaging in conflict with the others. "Because cosmopolitanism engenders ironic self-reflection, it does not need a strong or hot version of otherness, because its own identity is not profoundly shaped in conflict with others" (Turner, 2002: 57).

\section{Citizenship, membership and belonging between modernity and postmodernity}

How are the above briefly outlined formulae of cosmopolitan citizenship, based on invocation of past European legacies of stoicism and Enlightenment, attuned to the developments and conflicts of the contemporary global world? To address the question, a general observation as regards social and political transformation from modernity to postmodernity needs to be laid out. In the limited scope of this paper, this is done through the discussion of three major issues of citizenship, membership and belonging.

In classical modern theory, citizenship - to begin with the first - is defined as a tool of the nation state that binds the individual to the state and, by connecting legal to political membership, creates conditions for solidarity (Štiks, 2010). Today - it has been observed - solidarity is in crisis because nation-states are in decline (Delanty and Rumford, 2005). The social fears of the others, which orchestrates political and public discourse in the contemporary EU, is borne on the perception that citizens have been let down by the state and its social welfare infrastructure - before they, the loyal subjects of the national project, could have harvested the historic fruits of the nation-state formation (Delanty, 2008; Zubaida, in Özkırıml1, 2000). This attitude, secondly, affects the notion of membership. Membership includes the legal, political and cultural aspects of life in a community; it is both a replica of citizenship and its surplus as it also collides with imaginary deliberations of one's worthiness and trustfulness to be a member. Belonging, finally, includes the territorial element that confirms and transcends the locality of the community. On the one hand, belonging is defined and defended by the discourses of "origin", "descent", "authenticity", ... bound to the land; on the other hand, belonging is de-territorialised by universalism (e.g., human rights), 
which transcends symbolic bonds of the local, and bounded community onto the plains of borderless humanity.

In modern conceptualisation, membership - be it political, legal or cultural - is defined by the institution of national citizenship. By the end of the $19^{\text {th }}$ century, national citizenship becomes the hegemonic form of collective membership and individual identity (Turner, 2002). Of course, citizenship is imagined differently in different societies and also within a given society; it can be both an instrument of inclusion and exclusion; a source of political mobilisation and emancipation; as well as a tool of depolitisation of population (Yuval-Davis, 1997). In liberal tradition, citizens are granted equal status, rights and duties despite sex/ gender, ethnicity, class or other social markings. An important aspect of this harmonisation of citizenship regardless of social difference is that "citizens are therefore constructed not as 'members of the community' but as strangers to each other, although they are sharing a complex set of assumptions and expectations about each other which, when not fulfilled, can be enforceable by the state" (Yuval-Davis, 1997: 70). An obvious problem, as can already be inferred from Kristeva's argument explicated above, is that with liberal abstractions of strangeness, the notions of rights and duties become obfuscated and de-territorialised; rights and duties are always implemented within the contexts of a given community. Moreover, social and cultural embeddedness of identity (together with difference) is obscured (Squires, 2002: 229). In addition, today's recognition of group rights has been an important aspect in the debate on democratisation of increasingly multicultural and poly-ethnic societies (Kymlicka, 1995, 2007). "In this respect," Delanty and Rumford write, "citizenship must be capable of a certain flexibility, for example in reconciling individual and group interests" (Delanty and Rumford, 2005: 87).

The republican model, on the other hand, relies on the existence of a strong community, bound together by "'enduring attachment', which often is, but not necessarily so, a result of a myth of common origin and is clearly bonded by a myth of common destiny" (Yuval-Davis, 1997: 71). However, the strength of the community is assured by the ethno-national principle; the civic model of nation that emphasises diversity and cultural indifference as regards origins, loses ground. The ground is lost also to all groups within the ethno-national communities that have already been pushed to the margins of the nation by processes of ethnic homogenisation, and assigned to the symbolic and cultural territory of the "others" (e.g., the Roma). New minorities and all the other marginalised groups without 
territorial or historic continuity become equally groundless: the republican model does not answer the question, "what should happen to those members of the civil society who cannot or would not become full members of that "community"' (Yuval-Davis, 1997: 71).

In sum, classical modern models of citizenship are facing a challenge today. "The phenomena of the territorial state, the nation, and a popular economy constituted within national borders formed a historical constellation in which the democratic process assumed a more or less convincing institutional form" (Habermas, 2001: 60). Contemporary processes of globalisation have announced the end to the constellation in which a part of society looked over the society as a whole. The historical era in which the model of political organisation was represented by the nation state, is giving way to the post-national era. The bond between "constitutional state" and nation is being broken. In addition, post-war migrations in Europe prove that "national citizenship is losing ground to a more universal model of membership, anchored in deterritorialized notions of persons' rights" (Soysal, 1994: 3). However, the contradictions between normative and organisational aspects of rights remain active: "While the source and legitimacy of rights is increasingly located in the transnational order, individual rights continue to be organized differentially, country by country, and bear the imprint of polity-specific forms of membership and incorporation. A similar disparity appears between two constitutive aspects of citizenship - identity and rights. Whereas rights, and claims to rights, become universalized and abstract, identity is still conceived of as particular and bounded by national, ethnic, regional, or other characteristics" (Soysal, 1994: 8).

The antagonisms between bounded and territorially defined belonging on the one hand, and universal and de-territorialised human rights create dialectical tensions, which call for the conceptualisation of new, post-national model of membership.

\section{The cosmopolitan turn}

Multicultural citizenship has seemed to be, until recently, a most productive alternative to the ethno-nationalist model. However, notwithstanding the most current denouncement of its success, the paradigm has suffered from serious flaws in concepts. In particular, the notion of multicultural recognition of differences presumes the existence of cultures that are stable in meaning and content, and dividable by transparent borders. Instead of decomposing, multiculturalism reaffirms the repressive discourse of cultural difference. In addition, the prefix multi- does not leave room for the inves- 
tigation of how cultures are internally diverse, dispersed and hybridised. Instead, it insists on co-existence of differences between cultures. "In multiculturalist policies, the naturalization of the western hegemonic culture continues while the minority cultures become reified and differentiated from normative human behaviour" (Yuval-Davis, 1997: 56). Can cosmopolitanism address as well as override some of these difficulties?

Cosmopolitanism encounters a serious problem when it comes to signifying democratic politics of practice. Two main concerns can be raised here. First, cosmopolitanism is usually imagined to be a democratic alternative to the parochialism and narrow-mindedness of nationalism (Calhoun, 2008). Therefore, it is seen as nationalism's other. However, by emphasising the shifting bond of belonging and de-territorialisation of identity, cosmopolitan discourse is also easily seen as unpatriotic, as having no regard for the homeland or for the history and memory of the community that occupies the lands of the nation-state. In a way, cosmopolitanism and nationalism become struggling parties in the definition of patriotism and, with the cosmopolitans not being seriously concerned with the issues of national identification, they by definition fall out as illegitimate agents in the formulation of public culture. By engaging in global politics of belonging and citizenship - the politics which re-examine the maps of the civilisational and cultural constellations of modernity (Delanty, 2005, 2009) - they (wrongly) appear as parties whose arguments are irrelevant to local politics: they are both above and beyond the national concern.

Because cosmopolitanism is largely associated in popular perception with the elites, it easily becomes regarded as alienated from the general public. It attracts the aura of insensitivity to the real issues and problems of ordinary people. It becomes synonymous with an intellectual fashion and cultural trend that is reserved for the few - the few whose concerns do not resonate with the concerns of the masses. In its capacity to attract the negative stigma of privilege and recreational practice that is linked to the self-consuming elites, the critical potentials that are relevant to the public, and to the everyday life of the national community, get lost from public sight. This, as we will argue, is indeed the major theoretical and political predicament that needs to be taken into account when talking about cosmopolitanism in Europe post-1989.

To address these problems, one can start with Varsamopoulou that "[s]uffice it is to say that, if nationalism is an obstacle to cosmopolitanism, to regress into a new or nostalgic imperialism cannot be the answer" (Varsamopoulou, 2009: 27). In other words, to return to history and revitalise its legacies may be an entertaining intellectual endeavour but it certainly is far 
from matching the demands of the contemporary world. In the remainder of the paper, we illustrate this with the case of post-socialist Slovenia.

\section{Post-socialist citizenship: the case of Slovenia}

The break-up of Yugoslavia and the institutional and ideological constructions of citizenship in post-socialist Slovenia can be used as a proper case study to observe the impasse that theories of cosmopolitanism encounter when faced with concrete historical and political situations, triggered by social transformation and change. From the outset, the move of Slovenia towards independence has been a process ridden with ambiguities as regards democratic development and introduction of an open and multicultural model of society. Whereas the strong right-wing rhetoric emphasised how democratisation of society would be carried out in direct opposition to repressive techniques of government, imposed on the republic by the former federal state, in reality, "ethnic homogenisation and hostility towards all who were different" (Mastnak, 1992: 211) was carried out. Instead of democratisation and pluralisation of belonging and membership, a closed and often xenophobic model of national homogenisation and ethnic engineering took place (Vidmar-Horvat and Delanty, 2008; Vidmar Horvat, 2009). Whereas on the political right, the introduction of oppressive regimes of national belonging was defended on the ground of the historical right of the dominant ethnic group to exhort its power over society at large - this legitimation discourse could be found across post-socialist Central and Eastern Europe (Forrester, Zaborowska and Gapova, 2004) - on the left, the traumas caused by post-socialist nationalism were often explained (away) by the predicaments of the transition. Therefore, whereas political parties differed in the way they legitimised the exclusionary politics of the state and society, they spoke the same language as far as the nationalist revitalisation of society was concerned. This was most evident in the crossparty employment of discourses of Europeanisation, de-Balkanisation, and also cosmopolitisation (!) of Slovene national culture and identity (Petrović, 2009; Velikonja, 2005; Vidmar Horvat and Nieminen, 2010).

When discussing the "laboratory of citizenship" in the post-Yugoslav Balkan region, Igor Štiks (2010) identifies four major moves in which citizenship was reorganised. The first group were the included. The included gained their citizenship status on the basis of the principle of legal continuity between new citizenship and previous republican citizenship. "Possessing the citizenship of the new state was essential when individuals requested new documents such as IDs and passports but also for maintaining previously held jobs, access to health care, and property rights" (Štiks, 
2010: 12). The issue could arise if the registers were incomplete or incomplete due to administrative floppiness. The real problem of gaining new citizenship, however, concerned the Yugoslav citizens who resided outside the republic of their original citizenship. As Štiks also noted for residents in post-Soviet Estonia and Latvia, a sizable Russophone population was excluded from citizenship; the same, as it will soon be discussed, holds true also for Slovenia.

The next group were the invited. The post-socialist states were eager to invite certain individuals or groups, mostly ethnic kin. The new law on Croatian citizenship in 1991 made the invitation explicit: the invited included ethnic Croats who resided in Croatia but did not have citizenship status; Croats residing in Bosnia-Herzegovina; and members of diasporas in Europe and overseas. The same invitation to take Bosnian citizenship was issued by Bosnia-Herzegovina, but the multi-national country invited only those who had already been residing on the republic's territory on 6 April 1992 (the day of the international recognition and the beginning of the war). Some questionable invitations were nonetheless issued, in particular to a limited number of foreigners from Islamic countries who had fought on the Bosniac side during the war, as well as to Serbs and Bosniacs from the Sandžak region (Štiks, 2010: 13). In Slovenia, the invitation was sent to ethnic Slovenians in Argentina: some of them actually accepted the offer - only to find later that the Motherland did not prove to be as motherly as it promised to be.

The next two categories were the excluded and the self-excluded. To begin with the latter, some ethnic groups saw the break-up of Yugoslavia as an opportunity to secede from the republic of residence and join the kin state. This was the case with Croats and Serbs in Bosnia-Herzegovina. A "peaceful rebellion" of Albanians in Kosovo by self-exclusion was practised until the emergence of the Kosovo Liberation Army in 1997. In Slovenia, self-exclusion was limited to a small number of residents, mainly former Yugoslav Army officers who declined Slovenian citizenship - some actually moving out of the country. Their case, however, was highly publicised to hyperbolise the danger of the alleged "fifth column" within the society.

The nationalist populist pointing to the self-excluded in Slovenia carried a most tragic effect in the case of the erased - a group of excluded who did not know (for years) that they had been collectively removed from registers. On 23 February 1992, over 22,000 ethnically non-Slovene lawful residents from other republics thus became "erased". Their documents became invalidated, which meant the loss of jobs, social and health security as well as all the other benefits. From an administrative point of view, they became "dead" (Štiks, 2010: 16), and from the societal perspective, 
non-existent. A major tactic employed by the supporters of the erasure was that the erased did not care to obtain citizenship; that they demanded the erasure to be revoked in order to later make financial claims for their suffering; and that their loyalty was always with other, non-Slovene republics. The argument was prolonged on to the first generation born to the erased parents already in Slovenia (for a full debate, see Mandelc and Učakar, 2011; also Učakar, 2009).

Based on the analysis provided by Štiks (2010), two key characteristics of the post-socialist politics of citizenship can be observed. Both allow us to delineate major historical differences between modern and postmodern nationalisation of society. First, the case of post-socialist Slovenia shows how the nationalist "laboratory of citizenship" was run in sharp contrast to the $19^{\text {th }}$ century model. Whereas the romantic ideological platform of revitalisation of the $19^{\text {th }}$ century nation was employed (this was most evident in the narrative of the "return to Mitteleuropa" /Vidmar-Horvat and Delanty, 2008/), appropriation of the modern legacy of the nation-building was profoundly reconstructed. Reconstruction unfolded in a way that did not launch the ideal of the nation-state as the rule of the law and protector of basic human rights; instead, it introduced a model that privileged the dominant ethnic group's right to withdraw human and citizenship rights from the groups deemed "disloyal" to the state. The rights could be withdrawn arbitrarily and prior to any legal deliberation. In contrast to the experience of the citizens in ancient Athens, who could always rely on the help of the neighbours and the community to provide proof of their legal status, the erasure of residents from the register in post-socialist Slovenia occurred in the context of a general public amnesia of their presence only yesterday in local and national life.

Secondly, ethnic engineering in all successor states was carried out with the help of cultural homogenisation. In contrast to the 19th century historically progressive model, this was done through a historically regressive model. Instead of homogenisation by means of civic education and democratic citizenship, as articulated in the idea of "horizontal brotherhood" (Anderson, 1991), exclusionary ethnic "purification" and "ethnic cleansing" were the preferable methods of unification and solidarity. In Croatia, this was done primarily through "re-Catholicisation"; in Slovenia through "de-Balkanisation". In Slovenia, the results were twofold: firstly, civic solidarity was replaced by a reactionary ethnic solidarity. Secondly, the society regressed from a relatively open model of membership, as practised in socialist Yugoslavia (hospitality to immigrants, legal equality), to a closed model (hostility and re-bordering). 
In sum, the process of post-socialist renationalisation of citizenship in the Western Balkans, which followed the break-up of Yugoslavia, was carried out in (often) violent reclaiming of territory and re-erection of both administrative and symbolic borders of belonging and membership. In Slovenia, the reconstitution of ethno-national geographies of belonging had a major effect on the new immigrants. For those who came from the ex-Yugoslav region, this meant facing a stigma of otherness which, in light of memories of former shared participation in Tito's project of "unity and brotherhood", carried a special traumatising effect of being let down (Jansen, 2009). For those who settled in Slovenia temporarily as refugees and asylum seekers, the nationalist euphoria made them vulnerable objects in the social and cultural reconstruction of the nation. Notwithstanding their maltreatment by the state and its social institutions, they involuntarily participated in the construction of the cordon sanitaire image of Slovenia as a "proper" European nation (Mihelj, 2004). As the story of the erased unveils, residents who had already participated in the political body of Slovene society as Yugoslav citizens, on the other hand, became status- and state-less overnight. Collective apatrids without conducting any act of movement, they have been legally and socially incomparable both to today's global immigrants and to metics of the past. To them, cosmopolitan fascination with up-rootedness up to today can mean only a drama of enforced exile while staying immobile in place and history.

\section{Instead of a conclusion}

What lessons can be drawn from the Slovenian post-socialist model of citizenship? Three main observations can be made, on the basis of which a cosmopolitan agenda could be reconsidered. Firstly, in contrast to the cosmopolitan ideal of self-estrangement, the reality of today's migration and mobility is ridden with narratives, practices and politics of forced movement and de-territorialisation. These legacies in the making undermine the cosmopolitan ethos that thrives on discourses of self-estrangement. Next, fetishisation of the stranger as the ideal subject of cosmopolitan imagination overlooks the fact of how the de-territorialized and forcedly exiled yearn for territoriality and local belonging in their new places of residence. In fact, "the most critical resistance strategy for disempowered groups is to occupy and defend a politics of social location rather than to vacate and destroy it" (Squires, 2002: 241). The longing for home is not made an anachronism by the mere fact of leaving the home, nor is it abandoned once territorial borders are crossed (Huttunen, 2005). To be allowed to have a home for the displaced is an important signature of recognition by the 
host community, as well as a measure of social, cultural and political power of the immigrants in their new environment. Finally, strangeness is not the category that can annihilate cultural histories of the territory. When Kristeva (1991) travels to her exile of the new strangers, she conveniently forgets, as Varsamopoulou effectively argues, how the land which her intellectual mind wants to occupy as a home of new humanity, had been pre-inhabited by the native Americans; the vision of these early colonised "strangers" of the cosmopolitan immigrants may differ from that of the philosopher from Europe. The erased, on the other end of the spectrum of dispossession of land and belonging, also attest to how the notions of roots and territorial histories can easily become re-arranged in transition societies, whereas transition itself becomes a legitimising tool for the new counting of historical time - with the swing of the pendulum that may exclude also those who once already belonged to the land.

Considering the predicaments of cosmopolitan thought that tends to dehistoricise history as it embarks on de-territorialisation of belonging, it can be concluded that the critical challenge is how to bring cosmopolitanism home; how, in light of contradictory forces of de-territorialisation (global mobility) and re-territorialisation of societies (belonging, citizenship, membership), make the cosmopolitan agenda part and parcel of the negotiation of the political, cultural and social management of the territory - which will also include those without territory. To ground cosmopolitanism, therefore, requires efforts to make it part of the patria - of the home that is post-national and post-territorial, while furthering emancipatory legacies that have made it the basis of democratic citizenship, membership and belonging.

\section{REFERENCES}

Anderson, Benedict (1991). Imagined communities. London: Verso.

Appiah, Kwame Anthony (1997). "Cosmopolitan Patriots”, Critical Inquiry, 23 (3): 617-639. doi:10.1086/448846

Balibar, Étienne (2004). We, the People of Europe? Reflections on Transnational Citizenship. Princeton: Princeton University Press.

Benhabib, Seyla (2004). The Rights of Others: Aliens, Residents, and Citizens. Cambridge: Cambridge University Press. doi:10.1017/CBO9780511790799

Benhabib, Seyla (2006). Another Cosmopolitanism. Oxford: Oxford University Press.

Calavita, Kitty (2005). Immigrants at the Margins: Law, Race, and Exclusion in Southern Europe. Cambridge: Cambridge University Press.

doi:10.1017/CBO9780511493942 
Calhoun, Craig (2008). "Cosmopolitanism and nationalism", Nations and Nationalism, 14 (3): 427-448.

Delanty, Gerard (1996). "The Resonance of Mitteleuropa: A Habsburg Myth or Antipolitics?", Theory, Culture \& Society, 13 (4): 93-108. doi:10.1177/0263276496013004005

Delanty, Gerard (2005). "The Idea of a Cosmopolitan Europe: On the Cultural Significance of Europeanization", International Review of Sociology, 15 (3): 405-421. doi:10.1080/03906700500272434

Delanty, Gerard (2008). "Fear of Others: Social Exclusion and the European Crisis of Solidarity", Social Policy \& Administration, 42 (6): 676-690. doi:10.1111/j.1467-9515.2008.00631.x

Delanty, Gerard (2009). The Cosmopolitan Imagination: The Renewal of Critical Social Theory. Cambridge: Cambridge University Press.

Delanty, Gerard and Rumford, Chris (2005). Rethinking Europe: social theory and the implications of Europeanization. London: Routledge.

Featherstone, Mike (2006). "Genealogies of the Global", Theory, Culture \& Society, 23 (2-3): 387-392. doi:10.1177/0263276406062704

Forrester, Sibelan, Zaborowska, Magdalena J. and Gapova, Elena (eds) (2004). Over the Wall/After the Fall: Post-Communist Cultures through an East-West Gaze. Bloomington in Indianapolis: Indiana University Press.

Habermas, Jürgen (2001). The Postnational Constellation: Political Essays. Cambridge: Polity Press.

Held, David (2003). Cosmopolitanism: A Defence. Cambridge: Polity Press.

Huttunen, Laura (2005). "'Home' and ethnicity in the context of war: hesitant diasporas of Bosnian refugees", European Journal of Cultural Studies, 8 (2): 177-195. doi:10.1177/1367549405051843

Jansen, Stef (2009). "Cosmopolitan Openings and Closures in Post-Yugoslav Antinationalism", in: Magdalena Nowicka and Maria Rovisco (eds). Cosmopolitanism in Practice. Aldershot: Ashgate, pp. 75-92.

Kristeva, Julija (1991). Strangers to Ourselves. New York: Columbia University Press.

Kristeva, Julija (1993). Nations without Nationalism. New York: Columbia University Press.

Kymlicka, Will (1995). Multicultural Citizenship: A Liberal Theory of Minority Rights. Oxford: Clarendon Press.

Kymlicka, Will (2007). Multicultural Odysseys: Navigating the New International Politics of Diversity. Oxford: Oxford University Press.

Mandelc, Damjan and Učakar, Tjaša (2011). "Perforated Democracy: Disintegration, State-building, Europeanisation and the Erased of Slovenia", Revija za sociologiju, 41 (1): 27-49. doi:10.5613/rzs.41.1.3

Marotta, Vince P. (2010). "The Cosmopolitan Stranger", in: Stan van Hooft and Wim Vandekerckhove (eds). Questioning Cosmopolitanism. Dordrecht: Springer, pp. 105-120. doi:10.1007/978-90-481-8704-1_7

Mastnak, Tomaž (1992). Vzhodno od raja: civilna družba pod komunizmom in po njem. Ljubljana: Državna založba Slovenije. 
McGhee, Derek (2008). The End of Multiculturalism? Terrorism, Integration and Human Rights. Maidenhead: Open University Press.

Mihelj, Sabina (2004). "Negotiating European Identity at the Periphery: Media Coverage of Bosnian Refugees and 'Illegal Migration", in: Ib Bondebjerg and Peter Golding (eds). European Culture and the Media. Bristol: Intellect Books, pp. 165-189.

Nussbaum, Martha (1994). "Patriotism and Cosmopolitanism", Boston Review, 19 (5): 1-12, http://bostonreview.net/BR19.5/nussbaum.html.

Ossewaarde, Marinus (2007). "Cosmopolitanism and the Society of Strangers", Current Sociology, 55 (3): 367-388. doi:10.1177/0011392107076081

Özkırımlı, Umut (2000). Theories of Nationalism: A Critical Introduction. New York: Palgrave.

Petrović, Tanja (2009). A Long Way Home: Representations of the Western Balkans in Political and Media Discourses. Ljubljana: Peace Institute.

Rizman, Rudi (2008). "Negotiating Identity in the Age of Globalization", in: Ksenija Vidmar Horvat (ed.). The Future of Intercultural Dialogue in Europe: Views from the In-Between. Ljubljana: Znanstvenoraziskovalni inštitut Filozofske fakultete, pp. 33-45.

Rumford, Chris (2008). Cosmopolitian Spaces: Europe, Globalization, Theory. New York: Routledge.

Skrbiš, Zlatko, Kendall, Gavin and Woodward, Ian (2004). "Locating Cosmopolitanism: Between Humanist Ideal and Grounded Social Category", Theory, Culture \& Society, 21 (6): 115-136. doi:10.1177/0263276404047418

Squires, Judith (2002). "Terms of Inclusion: Citizenship and the Shaping of Ethnonational Identities", in: Steve Fenton and Stephen May (eds). Ethnonational Identities. Basingstoke: Palgrave Macmillan, pp. 227-251.

Soysal, Yasemin Nuhoğlu (1994). Limits of Citizenship: Migrants and Postnational Membership in Europe. Chicago and London: University of Chicago Press.

Štiks, Igor (2010). "A Laboratory of Citizenship: Shifting Conceptions of Citizenship in Yugoslavia and its Successor States" (University of Edinburgh, CITSEE Working Paper 2010/02), http://www.law.ed.ac.uk/publications/workingpapers. aspx.

Turner, Bryan S. (2002). "Cosmopolitan Virtue, Globalization and Patriotism", Theory, Culture \& Society, 19 (1-2): 45-63. doi:10.1177/026327640201900102

Učakar, Tjaša (2009). Izbris ali prenos: boj za interpretacijo izbrisanih. Diplomsko delo. Ljubljana: Filozofska fakulteta.

Van Wichelen, Sonja and De Leeuw, Marc (2008). "Transformations of 'Dutchness': From Happy Multiculturalism to the Crisis of Dutch Liberalism", in: Ksenija Vidmar Horvat (ed.). The Future of Intercultural Dialogue in Europe: Views from the In-Between. Ljubljana: Znanstvenoraziskovalni inštitut Filozofske fakultete, pp. 121-135.

Varsamopoulou, Evy (2009). "The Idea of Europe and the Ideal of Cosmopolitanism in the Work of Julia Kristeva", Theory, Culture \& Society, 26 (1): 24-44. doi:10.1177/0263276408099014

Velikonja, Mitja (2005). Eurosis - A Critique of the New Eurocentrism. Ljubljana: Peace Institute. 
Vertovec, Steven and Cohen, Robin (2002). "Introduction: Conceiving Cosmopolitanism", in: Steven Vertovec and Robin Cohen (eds). Conceiving Cosmopolitanism: Theory, Context, and Practice. Oxford: Oxford University Press, pp. 1-22.

Vidmar Horvat, Ksenija (2009). Zemljevidi vmesnosti: eseji o evropski kulturi in identiteti po koncu hladne vojne. Ljubljana: Sophia.

Vidmar-Horvat, Ksenija and Delanty, Gerard (2008). "Mitteleuropa and the European Heritage", European Journal of Social Theory, 11 (2): 203-218. doi:10.1177/1368431007087474

Vidmar Horvat, Ksenija and Nieminen, Hannu (2010). "Patriotic Media and the European Public Sphere: A Comparative Analysis of the News Coverage of the Patria Affair in Slovenia and Finland", IAMCR Conference Communication and Citizenship, Braga (Portugal), 18-22 July 2010.

Yuval-Davis, Nira (1997). Gender \& Nation. London: Sage.

\title{
Od meteka do izbrisanih ili kako utemeljiti kozmopolitizam: postsocijalistički pogled na suvremene teorije kozmopolitizma
}

\author{
Ksenija VIDMAR HORVAT \\ Odsjek za sociologiju Filozofskog fakulteta Sveučilišta u Ljubljani, Slovenija \\ ksenija.vidmar@ff.uni-lj.si
}

U članku se kritički pridonosi suvremenoj teoriji kozmopolitizma, a pritom se uzimaju u obzir specifični društveno-kulturni i politički konteksti postsocijalističke srednje i istočne Europe. Tvrdi se da kozmopolitizam može postati učinkovita politika i praksa demokratskoga građanstva samo ako se ugradi u svakodnevne procese pregovaranja o lojalnosti i patriotizmu prema nacionalnom društvu. U tom ga se smislu ne bi smjelo konceptualizirati kao drugi nacionalizam, nego prije kao alternativni patriotski osjećaj, koji združuje globalni etos humanosti i odgovornost prema političkoj i kulturnoj organizaciji lokalnoga društvenog života. Takav se pristup u ovome radu osvjetljava iz perspektive postsocijalističkoga građanstva u Sloveniji i tragičnoga iskustva »izbrisanih«.

Ključne riječi: kozmopolitizam, građanstvo (građanski status), postsocijalizam, nacionalizam, Balkan, bivša Jugoslavija, Slovenija 